\title{
The Role of Histamine and Serotonin in the Control of Vascular Motricity of the Anterior Ocular Segment - Review of the Literature from 1997 to 2018
}

\author{
Dragos-Constantin Lunca ${ }^{1,3}$, Horia Paunescu' ${ }^{1}$ Laurentiu Coman², Ion Fulga?
}

\begin{abstract}
Histamine and serotonin, besides known systemic effects, can influence vascular tone at the eye level. The review of the literature from 1997 to 2018 suggests that these ocular effects are very variable - both vasodilation and vasoconstriction. Specific agonists or antagonists acting in the histamine and serotonin domains, are probably more useful than endogenous substances as working tools for discovering the functional elements involved in regulating ocular vascular tone. Knowing that intraocular pressure regulation also depends on the vascular tone of the anterior ocular segment, some of the substances under review may be candidates for potential intraocular pressure lowering drugs.
\end{abstract}

Keywords: histamine, serotonin, eye, iris, vascular tone

\section{Rezumat}

Histamina și serotonina, pe lângă efectele sistemice cunoscute, pot influența tonusul vascular de la nivel ocular. Recenzia literaturii de specialitate din perioada 1997-2018 a arătat că aceste efecte oculare sunt foarte variabile atât vasodilatație, cât și vasoconstricție. Substanțele care modulează la nivel de receptor aceste efecte (agoniștii și antagoniștii histaminergici și serotoninergici) sunt probabil mai utili decât substanțele endogene ca instrumente de lucru pentru descoperirea elementelor funcționale implicate în reglarea tonusului vascular ocular. Cunoscând că reglarea presiunii intraoculare depinde și de tonusul vascular al segmentului anterior ocular, unele din substanțele recenzate ar putea prezenta și efecte hipotonizante oculare.

Cuvinte cheie: histamină, serotonină, ochi, iris, tonus vascular

1 Department of Pharmacology and Pharmacotherapy, Faculty of Medicine, "Carol Davila" University of Medicine and Pharmacy, Bucharest, Romania

2 Department of Physiology, Faculty of Pharmacy, "Carol Davila" University of Medicine and Pharmacy Bucharest, Romania

${ }^{3}$ Department of Ophthalmology, „Dr. Carol Davila” Central Military Emergency University Hospital, Bucharest, Romania

\section{Corresponding author.}

Horia Paunescu, Faculty of Medicine, $8^{\text {th }}$ Eroilor Sanitari Boulevard, $5^{\text {th }}$ District, Bucharest, Romania.

E-mail:phpaunescu@yahoo.com 


\section{INTRODUCTION}

Histamine and serotonin (5-hydroxytryptamine) are two amino acid derivatives with important biological functions ${ }^{1}$.

Histamine, an endogenous monoamine, is synthesized from the histidine and is stored in most tissues and degraded in liver by histaminase. The most important roles of histamine are: mediation of type I allergic reactions, stimulation of stomach secretion of hydrochloric acid and pepsin (as autacoid), and functioning as a neurotransmitter (especially in the central nervous system $)^{2}$. Regarding the vascular effects of histamine in non-ocular territories, there have not been many published literature reviews, for example, there are data reviewed for pulmonary artery ${ }^{3}$, brain territory ${ }^{4}$, but these data are not recent.

Serotonin (5-HT), synthesized from the tryptophan, exhibits vascular effects, which began to be studied a few years after its discovery (the "vasoconstrictionproducing serum substance" described and identified as 5-hydroxytryptamine by Rapport in 1948) ${ }^{5}$. Several reviews about the cardiovascular effects of serotonin ${ }^{6}$ have been published.

\section{AlM}

This paper aims to evaluate the influence of histamine, serotonin and related substances acting on histamine and serotonin receptors upon anterior ocular vascularisation by studying the literature from 1997-2018.

For the purpose of explaining the working method of the reviewed scientific articles, it is necessary to present a brief introduction to the vascular anatomy of the anterior ocular segment.

\section{Anatomical data on anterior eye segment vascularization}

Choroid vascularization includes ophthalmic artery branches: two long posterior ciliary arteries (LPCA) and a variable number of two to four short ciliary arteries originated either in the ophthalmic artery or LPCA. The iris and the ciliary body are considered to be a unitary one because they have the same embryological origin and the same arterial vasculature, mainly provided by the LPCA. Anterior ciliary arteries are described in humans, but are absent in some mammalian species (e.g., in the rat). At the level of the ocular equator, the two LPCAs pass from the supra-corodial space into the choroid, from where it continues to the ciliary body, at which level each vessel divides dichotomically - a dorso-anterior and a ventro-anterior branch to form the great arterial artery of the iris ${ }^{7}$.

\section{MATERIALS AND METHODS}

We used the pubmed.com electronic platform of the National Library of Medicine using a non-restrictive tag: "(histamine OR serotonine OR 5-HT OR 5-hydroxytryptamine) AND (eye OR eye) AND (vessels OR arteries OR veins)". The "Date publication" filter was chosen between 1997/01/01 and 2018/12/31. A total of 65 articles resulted at the search performed on $2018 / 02 / 01$. It is noted that the interest in this field is slightly decreasing compared to the period 1984-2012 (see Figure 1). Of these, 20 articles of interest were selected by reading the abstracts (no articles referring strictly on retinal circulation were selected).

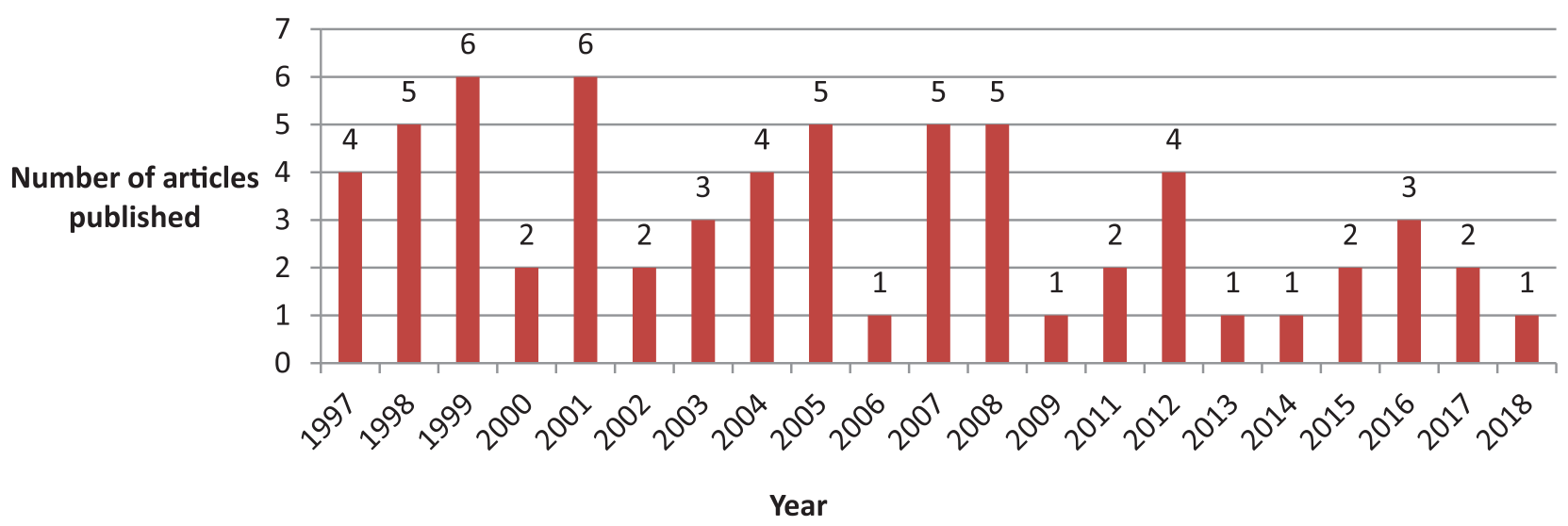

Figure 1. Distribution of the articles in the field of histamine, serotonin and eye anterior segment published in the period $1997-2018$. 
Dragos-Constantin Lunca et al.

Table 1.

\begin{tabular}{|c|c|c|c|c|c|}
\hline Substances & $\begin{array}{c}\text { VD } \\
\text { (VC antago- } \\
\text { nized) }\end{array}$ & $\begin{array}{c}\text { VC } \\
\text { (VD antago- } \\
\text { nized) }\end{array}$ & No effect & Spercies, teritory, method & References \\
\hline Histamine & & + & & $\begin{array}{l}\text { in vitro, normal rabbit, PC arteries in the presence or ab- } \\
\text { sence of endothelium }\end{array}$ & 11 \\
\hline L-NMMAa + Histamine & & + & & in vivo (i.v. administration), healthy men, choroid vessels & 12 \\
\hline Histamine & & + & & in vitro, normal rabbit, $\mathrm{PC}$ arteries & 13 \\
\hline Histamine & & + & & in vitro, normal rabbit, PC arteries & 14 \\
\hline Histamine & + & & & $\begin{array}{l}\text { in vivo (i.v. administration), in healthy men, choroid } \\
\text { vessels }\end{array}$ & 15 \\
\hline Histamine & & $+*$ & & in vitro, normal porcine, $\mathrm{PC}$ arteries & 16 \\
\hline Histamine & + & & & in vivo (i.v. administration), healthy men, choroid vessels & 17 \\
\hline Histamine + cimetidine & $+* \star$ & & & in vivo (i.v. administration), healthy men, choroid vessels & 17 \\
\hline Histamine & + & & & in vivo (i.v. administration), healthy men, choroid vessels & 18 \\
\hline $\begin{array}{l}\text { Histamine + diphenhy- } \\
\text { dramine }\end{array}$ & & + & & in vivo (i.v. administration), healthy men, choroid vessels & 18 \\
\hline Histamine & & + & & in vitro, normal rabbit, ciliary arteries (not specified) & 19 \\
\hline Histamine + pyrilamine & + & & & in vitro, normal rabbit, ciliary arteries (not specified) & 19 \\
\hline Histamine + cimetidine & & + & & in vitro, normal rabbit, ciliary arteries (not specified) & 19 \\
\hline $\begin{array}{l}\text { Histamine + Low } \\
\text { Calcium }\end{array}$ & $+* * *$ & & & in vitro, normal rabbit, ciliary arteries (not specified) & 19 \\
\hline Histamine + cimetidine & & + & & in vitro, normal porcine, ciliary arteries (not specified) & 20 \\
\hline $\begin{array}{l}\text { Histamine + cimetidine } \\
+ \text { mepyramine }\end{array}$ & + & & & in vitro, normal porcine, ciliary arteries (not specified) & 20 \\
\hline Histamine & + & & & in vivo (topical administration), normal rats, iris vessels & 21 \\
\hline $\begin{array}{l}\text { Promethazine + His- } \\
\text { tamine }\end{array}$ & & & + & in vivo (topical administration), normal rats, iris vessels & 21 \\
\hline Ranitidine + Histamine & + & & & in vivo (topical administration), normal rats, iris vessels & 21 \\
\hline Promethazine & & & + & in vivo (topical administration), normal rats, iris vessels & 21 \\
\hline Ranitidine & & + & & in vivo (topical administration), normal rats, iris vessels & 21 \\
\hline Histamine & + & & & $\begin{array}{l}\text { in vivo (topical administration), normal rats, conjunctival } \\
\text { vessels }\end{array}$ & 21 \\
\hline $\begin{array}{l}\text { Promethazine + His- } \\
\text { tamine }\end{array}$ & & & + & $\begin{array}{l}\text { in vivo (topical administration), normal rats, conjunctival } \\
\text { vessels }\end{array}$ & 21 \\
\hline Ranitidine + Histamine & + & & & $\begin{array}{l}\text { in vivo (topical administration), normal rats, conjunctival } \\
\text { vessels }\end{array}$ & 21 \\
\hline Promethazine & & & + & $\begin{array}{l}\text { in vivo (topical administration), normal rats, conjunctival } \\
\text { vessels }\end{array}$ & 21 \\
\hline Ranitidine & & & + & $\begin{array}{l}\text { in vivo (topical administration), normal rats, conjunctival } \\
\text { vessels }\end{array}$ & 21 \\
\hline Histamine (low Ca) & & + & & in vitro, normal rabbit, PC arteries & 22 \\
\hline $\begin{array}{l}\text { Histamine (low Ca)+ } \\
\text { high } \mathrm{K}\end{array}$ & & + & & in vitro, normal rabbit, $\mathrm{PC}$ arteries & 22 \\
\hline Histamine & + & & & $\begin{array}{l}\text { in vivo (topical administration), normal Guinea pigs, con- } \\
\text { junctival vessels }\end{array}$ & 23 \\
\hline Histamine (low Ca) & & + & & in vitro, normal rabbit, PC arteries & 24 \\
\hline $\begin{array}{l}\text { Histamine (low Ca) + } \\
\text { high K }\end{array}$ & & + & & in vitro, normal rabbit, PC arteries & 24 \\
\hline Histamine & & + & & in vitro, normal bovine, $\mathrm{PC}$ arteries & 25 \\
\hline $5-\mathrm{HT}$ & & + & & $\begin{array}{l}\text { in vitro, normal bovine, PC both endothelium intact and } \\
\text { denuded arteries }\end{array}$ & 26 \\
\hline $5-H T+L-N N A b$ & & $+* * * *$ & & $\begin{array}{l}\text { in vitro, normal bovine, PC both endothelium intact and } \\
\text { denuded arteries }\end{array}$ & 26 \\
\hline Ketanserin & + & & & $\begin{array}{l}\text { in vivo (topical administration), healthy men, choroid } \\
\text { vessels }\end{array}$ & 27 \\
\hline $5-\mathrm{HT}$ & & + & & in vitro, normal porcine, ciliary arteries (not specified) & 28 \\
\hline melatonin + 5- HT & + & & & in vitro, normal porcine, ciliary arteries(not specified) & 28 \\
\hline $5-\mathrm{HT}$ & & + & & in vitro, normal porcine, ciliary arteries (not specified) & 20 \\
\hline
\end{tabular}


Table 2.

\begin{tabular}{|c|c|c|c|c|c|}
\hline Domain & Agonist/antagonist receptors & Substances & Possible intracellular signalling & In vitro & In vivo \\
\hline \multirow{4}{*}{ H } & Histamine & & & VC & VD \\
\hline & $\mathrm{H}_{1}$ blockers & $\begin{array}{l}\text { promethazine, pyrilami- } \\
\text { ne, diphenhydramine }\end{array}$ & $\begin{array}{l}\text { Decrease } \mathrm{Ca}^{2+} \text { - Gq dependent, } \\
\text { Decrease NO }\end{array}$ & & $\begin{array}{l}\text { No effect } \\
\text { or } V C\end{array}$ \\
\hline & $\mathrm{H}_{2}$ blockers & cimetidine, ranitidine & \begin{tabular}{|l|} 
Decrease cAMP, \\
Decrease NO \\
\end{tabular} & & VC \\
\hline & $\mathrm{H}_{1}+\mathrm{H}_{2}$ blockers & & Decrease cAMP/Ca2+ signaling & VD & \\
\hline \multirow{10}{*}{$5-\mathrm{HT}$} & Serotonin & & & VC & $\begin{array}{l}\text { VD (unpubli- } \\
\text { shed results) }\end{array}$ \\
\hline & 5- $\mathrm{HT}_{1 \mathrm{~A}}$ agonist & 8-Hydroxy DPAT & Decrease cAMP & No effect & \\
\hline & $5-\mathrm{HT}_{2 \mathrm{~A}}$ agonist & R-DOI & Increase $\mathrm{Ca}^{2+}-\mathrm{Gq}$ dependent & VC & \\
\hline & $5-\mathrm{HT}_{2 \mathrm{~A} / 2 \mathrm{~B}}$ agonis & BW -723C86 & Increase $\mathrm{Ca}^{2+}-\mathrm{Gq}$ dependent & $\mathrm{VC}$ & \\
\hline & $5-\mathrm{HT}_{2 \mathrm{C}}$ agonist & MK-212 & Increase $\mathrm{Ca}^{2+}$ - Gq dependent & $\mathrm{VC}$ & \\
\hline & $5-\mathrm{HT}_{3}$ agonist & quipazine & $\begin{array}{l}\text { Increase } \mathrm{Na}^{+}=\mathrm{K}^{+}>\mathrm{Ca}^{2+} \text { trans- } \\
\text { membranary ion flux }\end{array}$ & No effect & \\
\hline & $5-\mathrm{HT}_{1 \mathrm{~B} / 1 \mathrm{D}}$ antagonist & Sumatriptan & Increase cAMP & No effect & \\
\hline & \multirow[t]{2}{*}{ 5- $\mathrm{HT}_{2 \mathrm{~A}}$ antagonists } & M-100907 & Decrease $\mathrm{Ca}^{2+} \mathrm{Gq}$ dependent & $\begin{array}{l}\text { Blocked VC } \\
\text { induced by } \\
5-\mathrm{HT}_{2 \mathrm{~A} / 2 \mathrm{~B}} \text { ago- } \\
\text { nist-induced }\end{array}$ & \\
\hline & & Ketanserin & $?$ & & VD \\
\hline & $5-\mathrm{HT}_{2 \mathrm{~B}}$ antagonists & RS-127445 & Decrease $\mathrm{Ca}^{2+}-\mathrm{Gq}$ dependent & $\begin{array}{l}\text { Blocked VC } \\
\text { induced by } \\
5-\mathrm{HT}_{2 \mathrm{~A} / 2 \mathrm{~B}} \text { ago- } \\
\text { nist }\end{array}$ & \\
\hline
\end{tabular}

The localization of specific $\mathrm{H}_{1}, \mathrm{H}_{2}, \mathrm{H}_{3}$ and $\mathrm{H}_{4}$ receptors in human and mammalian ocular structures is still elusive ${ }^{39}$.

According to some clinical observations, intraocular pressure (IOP) could be increased by $\mathrm{H}_{2}$ blockers (cimetidine and ranitidine $)^{40,41}$, data that was not found in the summary of each medicine product characteristics $^{42,43}$. It is very difficult to demonstrate the involvement of $\mathrm{H}_{1}$ receptors in the setting of IOP in clinical trials, as most $\mathrm{H}_{1}$ inverse agonists or antagonists also exhibit anticholinergic actions ${ }^{44}$.

Regarding earlier research conducted before 1997, in the data reviewed by Buckley et al.,1997, histamine was not studied in the PC arteries ${ }^{8}$. In one of the studies, histamine produced VD in the retinal arteries with intact endothelial artery, in vitro. In bovine eyes, VD is probably dependent on NO and cyclooxygenase $(\mathrm{COX})$. In human eyes, the VD component of the ophthalmic artery is $\mathrm{H}_{2}$-mediated and independent of vascular endothelium. In canide, VD is partially dependent of $\mathrm{H}_{2}$ receptors on vascular smooth muscle fibers, but is not (probably) dependent on endothelium. In bovine eyes and cat eyes, the histamine response is $\mathrm{VC}^{8,12}$.

In rat eyes, in vivo, histamine produced a statistically insignificant $\mathrm{VD}$ of the irian arteries and antagonized VC induced by ranitidine ${ }^{21}$. In vivo, histamine produ- ced VD of the conjunctival territory in Guinea pig eyes and at the level of choroidal vessels in humans ${ }^{23,12}$. In human eyes, histamine induced VD in the choroidal territory is NO dependent (VD is significantly attenuated by concomitant administration of L-NMMA). In the porcine ciliary arteries, in vitro, blocking $\mathrm{H}_{1}$ produces $\mathrm{VD}^{20}$.

$\mathrm{H}_{1}$ blockers have no effect on vascular size in rat iris $^{21}$.

$\mathrm{H}_{2}$ blockers have a VC effect in the rat in vivo ${ }^{21}$, but not in humans, in the choroidal territory ${ }^{17}$.

\section{The serotonin system}

There are 7 types of serotonin receptors, of which $5-\mathrm{HT}_{3}$ are ion channels, and $5-\mathrm{HT}_{1-2}$ and $5-\mathrm{HT}_{4-7}$ are coupled to $\mathrm{G}$ proteins ${ }^{45}$. Reviews of types and receptor subtypes have recently been published ${ }^{46,47}$.

The most common types and subtypes of the anterior segment of the eye are $5-\mathrm{HT}_{1 \mathrm{~A}}, 5-\mathrm{HT}_{2 \mathrm{~A}-2 \mathrm{C}}, 5-\mathrm{HT}_{3}$, $5-\mathrm{HT}_{4}, 5-\mathrm{HT}_{5}, 5-\mathrm{HT}_{7}{ }^{9,48} .5-\mathrm{HT}_{6}$ receptors were detected only at irian level, but are poorly expressed ${ }^{9,48}$.

\section{ROLES:}

Serotonin receptors and their intracellular signal transduction mechanisms are very complex. The importance of each mechanism is difficult to assess without the 
use of agonists or antagonists with specific action on these receptor types or subtypes. The review published by Sharif et al., 2010 presents the intraocular pressure lowering effect of at least 20 substances in Cynomolgus monkeys. 5- $\mathrm{HT}_{6}$ antagonists have shown intraocular pressure lowering effect, which may lead us to the conclusion that there are off-target effects of these very specific agonists or antagonists. The most obvious data on ocular hypotensive effect were obtained for $5-\mathrm{HT}_{2 \mathrm{~A}}$ agonists or $5-\mathrm{HT}_{2 \mathrm{~A}} / 5-\mathrm{HT}_{2 \mathrm{C}}$ mixt agonists 9

Very old research on feline and equine animal model showed that 5 -HT produces contraction of the iris sphincter muscle and relaxation of the iris radius mus$\mathrm{cle}^{49}$.

\section{EFFECTS AND LOCATION:}

$5-\mathrm{HT}_{1 \mathrm{~A}}$ receptors are mainly coupled to the $\mathrm{G}_{\mathrm{i}} / \mathrm{G}_{\mathrm{o}}$ protein family ${ }^{50}$ and are involved in the antioxidant protection of the retinal pigment epithelium ${ }^{51}$ and the function of the iris sphincter muscle ${ }^{52,49}$.

$5-\mathrm{HT}_{2 \mathrm{~A}}$ receptors are mainly coupled with the $\mathrm{G}_{\mathrm{q}}$ / $\mathrm{G}_{11}$ protein family ${ }^{53}$. The same type of intracellular coupling exists for $5-\mathrm{HT}_{2 \mathrm{~B}}$ and $5 \mathrm{HT}_{2 \mathrm{C}}$ receptors. There are some studies in animals and humans (Phase II studies) with $5-\mathrm{HT}_{2 \mathrm{~A}}$ agonists for the treatment of glaucoma ${ }^{9,48}$. They are found mostly at the trabecular meshwork. $5-\mathrm{HT}_{2 \mathrm{~B}}$ and $5-\mathrm{HT}_{2 \mathrm{C}}$ receptors are also involved in lowering IOP, with the remark that the $5-\mathrm{HT}_{2 \mathrm{C}}$ receptors are not constantly expressed in the ciliary body. They are especially found in the central nervous system.

$5-\mathrm{HT}_{3}$ receptors are ligand-dependent ion channels with the following ionic conductivity: $\mathrm{Na}^{+}=\mathrm{K}^{+}>\mathrm{Ca}^{2+}$ ${ }^{54} .5-\mathrm{HT}_{3}$ receptors are expressed inconstantly in the human ciliary body and probably play a minor role in regulating intraocular pressure ${ }^{9}$.

$5-\mathrm{HT}_{4}$ receptors are found in the ciliary body, choroida, conjunctiva and inconstantly in iris.

$5-\mathrm{HT}_{5}$ receptors are found in the ciliary body and iris.

\section{References}

1. Purves, D. et al. Neuroscience. (2012).

2. Forrester, J. V., Dick, A. D., McMenamin, P. G., Roberts, F. \& Pearlman, E. The eye: basic sciences in practice. (2016).

3. Barnes, P. J. \& Liu, S. F. Regulation of pulmonary vascular tone. Pharmacol. Rev. 47, 87-131 (1995).

4. Gross, P. M. Cerebral histamine: indications for neuronal and vascular regulation. J. Cereb. Blood Flow Metab. Off. J. Int. Soc. Cereb. Blood Flow Metab. 2, 3-23 (1982).

5. Rapport, M. M., Green, A. A. \& Page, I. H. Serum vasoconstrictor, serotonin; isolation and characterization. J. Biol. Chem. 176, 1243-1251 (1948).

6. Watts, S. W. The love of a lifetime: $5-\mathrm{HT}$ in the cardiovascular system. Am. J. Physiol. Regul. Integr. Comp. Physiol. 296, R252-256 (2009).
$5-\mathrm{HT}_{7}$ receptors were highlighted in the ciliary body, iris and conjunctiva ${ }^{48}$.

Earlier research from 1997 have shown that in vitro, 5-HT produces a vasoconstrictor effect of the ciliary and/or ophthalmic arteries of various species: canines, felines, bovines, monkeys and humans ${ }^{8}$. Our in vivo research on rats showed that the $2.5 \mathrm{mM}$ concentration of 5-HT topically applied to the eye surface, has an important VD effect in the iris arteries (our unpublished results).

Buckley et al. ${ }^{26}$ studied endothelial denuded bovine vessels, in which $5-\mathrm{HT}$ produced vasoconstriction. In vitro, vasoconstrictive effects of 5-HT have been highlighted in the literature since 1997. In ciliary arteries obtained from bovine and pigs eyes, various researchers have demonstrated that 5-HT administration, as well as specific or selective $5-\mathrm{HT}_{2}$ receptor subtypes agonists, produced vasoconstriction. A recent article, published by Njie-Mbye et al., 2018, showed that $5-\mathrm{HT}_{2}$ agonists $\left(5-\mathrm{HT}_{2 \mathrm{~A}}, 5-\mathrm{HT}_{2 \mathrm{~B}}, 5-\mathrm{HT}_{2 \mathrm{C}}\right)$ produced $\mathrm{VC}$ that can be antagonized by $5-\mathrm{HT}_{2}$ receptor blockers. $5-\mathrm{HT}_{1}$ receptor agonists did not produce vasoconstrictor effect in vitro ${ }^{30}$.

A list of effects obtained by in vitro or in vivo administration of the substances from the histamine and serotonin systems are presented in Table 2.

\section{CONCLUSIONS}

It is noted that administration of histamine or serotonin in different ways (topical - on the ocular surface, intravenously or in organ bath), may have opposite effects and is highly dependent on species and experimental conditions. Specific $5-\mathrm{HT}_{2}$ receptor agonists are probably vasoconstrictor substances, and $5-\mathrm{HT}_{2}$ blockade produces VD that could be a new way of lowering IOP. Regarding the histamine domain, it is difficult to find substances that cause VD or even decrease IOP.
7. Janes, R. G. \& Bounds, G. W. The blood vessels of the rat's eye. Am. J. Anat. 96, 357-373 (1955).

8. Buckley, C. H., Hadoke, P. W. \& O'Brien, C. J. Use of isolated ocular arteries in vitro to define the pathology of vascular changes in glaucoma. Br. J. Ophthalmol. 81, 599-607 (1997).

9. Sharif, N. A. Serotonin-2 receptor agonists as novel ocular hypotensive agents and their cellular and molecular mechanisms of action. Curr. Drug Targets 11, 978-993 (2010).

10. Zugravu, A. et al. A review on the physiological and pharmacological influence of vascular tone in choroidal and conjunctival eye territories. Farmacia 65, 656-662 (2016).

11. Yoshitomi, T., Ishikawa, H. \& Hayashi, E. Pharmacological effects of pilocarpine on rabbit ciliary artery. Curr. Eye Res. 20 254-259 (2000). 
12. Schmetterer, L. \& Polak, K. Role of nitric oxide in the control of ocular blood flow. Prog. Retin. Eye Res. 20, 823-847 (2001).

13. Hayashi, E., Yoshitomi, T., Ishikawa, H., Hayashi, R. \& Shimizu, K. Effects of isopropyl unoprostone on rabbit ciliary artery. Jpn. J. Ophthalmol. 44, 214-220 (2000).

14. Yoshitomi, T., Yamaji, K., Ishikawa, H. \& Ohnishi, Y. Vasodilatory mechanism of unoprostone isopropyl on isolated rabbit ciliary artery. Curr. Eye Res. 28, 167-174 (2004).

15. Zawinka, C., Resch, H., Schmetterer, L., Dorner, G. T. \& Garhofer, G. Intravenously administered histamine increases choroidal but not retinal blood flow. Invest. Ophthalmol. Vis. Sci. 45, 23372341 (2004).

16. Su, E., Yu, D. \& Cringle, S. Histamine induces opposing vasoactive effects at different levels of the ocular vasculature. Curr. Eye Res. 30, 205-212 (2005).

17. Resch, $H$. et al. Effect of histamine and cimetidine on retinal and choroidal blood flow in humans. Am. J. Physiol. Regul. Integr. Comp. Physiol. 289, R1387-1391 (2005).

18. Weigert, G., Zawinka, C., Resch, H., Schmetterer, L. \& Garhöfer, G. Intravenous administration of diphenhydramine reduces histamine-induced vasodilator effects in the retina and choroid. Invest. Ophthalmol. Vis. Sci. 47, 1096-1100 (2006)

19. Dong, Y., Ishikawa, H., Wu, Y. \& Yoshitomi, T. Vasodilatory mechanism of levobunolol on vascular smooth muscle cells. Exp. Eye Res. 84, 1039-1046 (2007).

20. Nagai, S., Tsurumaki, T., Abe, H. \& Higuchi, H. Functional serotonin and histamine receptor subtypes in porcine ciliary artery in comparison with middle cerebral artery. Eur. J. Pharmacol. 570, 159-166 (2007).

21. Coman, O. A. et al. Influencing vascular reactivity in vivo by histaminergic agonists and antagonists. Romanian J. Morphol. Embryol. Rev. Roum. Morphol. Embryol. 48, 403-406 (2007).

22. Dong, $Y$. et al. Relaxing effect and mechanism of tafluprost on isolated rabbit ciliary arteries. Exp. Eye Res. 87, 251-256 (2008).

23. Fukushima, A. \& Tomita, T. Image analyses of the kinetic changes of conjunctival hyperemia in histamine-induced conjunctivitis in Guinea pigs. Cornea 28, 694-698 (2009).

24. Watabe, H., Abe, S. \& Yoshitomi, T. Effects of Rho-associated protein kinase inhibitors Y-27632 and Y-39983 on isolated rabbit ciliary arteries. Jpn. J. Ophthalmol. 55, 411-417 (2011).

25. Ziganshina, A. P., Ziganshin, B. A. \& Ziganshin, A. U. Dual effects of ATP on isolated arteries of the bovine eye. Pharmacol. Res. 66, 170-176 (2012).

26. Buckley, C. H., Hadoke, P. W. \& O'Brien, C. J. Role of the endothelium in modulating functional responses of isolated bovine anterior ciliary arteries to vasoconstrictor agonists. Br. J. Ophthalmol. 82, 826-829 (1998).

27. Cellini, M. \& Caramazza, R. Color doppler imaging of ocular blood flow after topical ketanserin. Ophthalmol. J. Int. Ophtalmol. Int. J. Ophthalmol. Z. Augenheilkd. 213, 286-289 (1999).

28. Pache, M. et al. Effect of melatonin on vascular responses of porcine ciliary arteries. Curr. Eye Res. 24, 313-317 (2002).

29. Coman, O. A. et al. [Effects of serotonin on reactivity of ocular vasculature]. Oftalmol. Buchar. Rom. 1990 51, 126-133 (2007).

30. Njie-Mbye, Y. F. et al. Pharmacology of Serotonin Receptors Causing Contraction of Isolated Bovine Posterior Ciliary Arteries: Role in Ocular Blood Flow. J. Ocul. Pharmacol. Ther. Off. J. Assoc. Ocul. Pharmacol. Ther. (2018). doi:10.1089/jop.2017. 0124

31. guidetopharmacology.com Accesssed on 03/02/2018.

32. Bielory, L. \& Ghafoor, S. Histamine receptors and the conjunctiva. Curr. Opin. Allergy Clin. Immunol. 5, 437-440 (2005).

33. Inada, N., Shoji, J., Shiraki, Y., Aso, H. \& Yamagami, S. Histamine $\mathrm{H} 1$ and $\mathrm{H} 4$ receptor expression on the ocular surface of patients with chronic allergic conjunctival diseases. Allergol. Int. Off. J. Jpn. Soc. Allergol. 66, 586-593 (2017).

34. Abelson, M. B. \& Udell, I. J. H2-receptors in the human ocular surface. Arch. Ophthalmol. Chic. III 1960 99, 302-304 (1981).
35. Esbenshade, T. A. et al. The histamine $\mathrm{H} 3$ receptor: an attractive target for the treatment of cognitive disorders. Br. J. Pharmacol. 154, 1166-1181 (2008).

36. Yokota, E., Kuyama, S., Sugimoto, Y., Ogawa, M. \& Kamei, C. Participation of histamine $\mathrm{H} 3$ receptors in experimental allergic rhinitis of mice. J. Pharmacol. Sci. 108, 206-211 (2008).

37. Parsons, M. E. \& Ganellin, C. R. Histamine and its receptors. Br. J. Pharmacol. 147 Suppl 1, S127-135 (2006).

38. Paul Chazot, Hiroyuki Fukui, C. Robin Ganellin, Helmut L. Haas, Stephen J. Hill, Rebecca Hills, Roberto Levi, Walter Schunack, Jean-Charles Schwartz, Nigel P. Shankley, Henk Timmerman, J. Michael Young. Histamine receptors: $\mathrm{H} 1$ receptor. Last modified on 18/04/2017.Accessed on 04/02/2018. IUPHAR/BPS Guide to PHARMACOLOGY, http://www.guidetopharmacology. org/GRAC/ObjectDisplayForward?objectld=262.

39. Dey, S., Anand, B. S., Patel, J. \& Mitra, A. K. Transporters/receptors in the anterior chamber: pathways to explore ocular drug delivery strategies. Expert Opin. Biol. Ther. 3, 23-44 (2003).

40. Trzeciakowski, J. P. \& Frye, G. D. Effects of intraventricular histamine and $\mathrm{H} 2$ receptor antagonists on intraocular pressure. J. Ocul. Pharmacol. 3, 55-61 (1987)

41. Dobrilla, G., Felder, M., Chilovi, F. \& de Pretis, G. Exacerbation of glaucoma associated with both cimetidine and ranitidine. Lancet Lond. Engl. 1, 1078 (1982).

42. Cimetidine Summary of product characteristics.

43. Ranitidine Summary of product characteristcs.

44. Orzechowski, R. F., Currie, D. S. \& Valancius, C. A. Comparative anticholinergic activities of 10 histamine $\mathrm{H} 1$ receptor antagonists in two functional models. Eur. J. Pharmacol. 506, 257-264 (2005).

45. Nicholas M. Barnes, Daniel Hoyer, Rodrigo Andrade, Gordon Baxter, Joel Bockaert, Theresa Branchek, Marlene L. Cohen, Aline Dumuis, Richard M. Eglen, Manfred Göthert, Mark Hamblin, Michel Hamon, Paul R. Hartig, René Hen, Katharine HerrickDavis, Rebecca Hills, Patrick P. A. Humphrey, Klaus Peter Latté, Luc Maroteaux, Graeme R. Martin, Derek N. Middlemiss, Ewan Mylecharane, Stephen J. Peroutka, Pramod R. Saxena, Andrew Sleight, Carlos M. Villalon, Frank Yocca. 5-Hydroxytryptamine receptors. Accessed on 11/02/2018. IUPHAR/BPS Guide to PHARMACOLOGY, http://www.guidetopharmacology.org/ GRAC/FamilyDisplayForward?familyld=1

46. Costescu, M. et al. Pharmacodynamics of Serotonin. Emphasis on 5HT-3 Antagonists and SSRI Medication (I). Mod. Med. 23, 149-155 (2016)

47. Costescu, M. et al. Pharmacodynamics of Serotonin. Emphasis on 5HT-3 Antagonists and SSRI Medication (II). Mod. Med. 24 5-10 (2017).

48. Sharif, N. A. \& Senchyna, M. Serotonin receptor subtype mRNA expression in human ocular tissues, determined by RT-PCR. Mol. Vis. 12, 1040-1047 (2006).

49. Erspamer, V. Peripheral physiological and pharmacological actions of indolealkylamines. in 5-Hydroxytryptamine and Related Indolealkylamines (ed. Erspamer, V.) 245-359 (Springer Berlin Heidelberg, 1966). doi:10.1007/978-3-642-85467-5_7

50. Rodrigo Andrade, Nicholas M. Barnes, Gordon Baxter, Joel Bockaert, Theresa Branchek, Marlene L. Cohen, AlineDumuis, Richard M. Eglen, Manfred Göthert, Mark Hamblin, Michel Hamon, Paul R. Hartig, René Hen, Katharine Herrick-Davis, Rebecca Hills, Daniel Hoyer, Patrick P. A. Humphrey, Klaus Peter Latté, Luc Maroteaux, Graeme R. Martin, Derek N. Middlemiss, Ewan Mylecharane, Stephen J. Peroutka, Pramod R. Saxena, Andrew Sleight, Carlos M. Villalon, Frank Yocca. 5-Hydroxytryptamine receptors: 5-HT1A receptor. Last modified on 31/03/2017.Accessed on 04/02/2018. IUPHAR/BPS Guide to PHARMACOLOGY, http://www.guidetopharmacology.org/GRAC/ObjectDisp layForward?objectld=1.).

51. Biswal, M. R. et al. Systemic treatment with a 5HT1 a agonist induces anti-oxidant protection and preserves the retina from mitochondrial oxidative stress. Exp. Eye Res. 140, 94-105 (2015). 
52. Barnett, N. L. \& Osborne, N. N. The effect of serotonin on the rabbit isolated iris sphincter muscle. Curr. Eye Res. 12, 665-673 (1993).

53. Rodrigo Andrade, Nicholas M. Barnes, Gordon Baxter, Joel Bockaert, Theresa Branchek, Marlene L. Cohen, AlineDumuis, Richard M. Eglen, Manfred Göthert, Mark Hamblin, Michel Hamon, Paul R. Hartig, René Hen, Katharine Herrick-Davis, Rebecca Hills, Daniel Hoyer, Patrick P. A. Humphrey, Klaus Peter Latté, Luc Maroteaux, Graeme R. Martin, Derek N. Middlemiss, Ewan Mylecharane, Stephen J. Peroutka, Pramod R. Saxena, Andrew
Sleight, Carlos M. Villalon, Frank Yocca. 5-Hydroxytryptamine receptors: 5-HT2A receptor. Last modified on 16/05/2017.Accessed on 04/02/2018. IUPHAR/BPS Guide to PHARMACOLOGY, http://www.guidetopharmacology.org/GRAC/ObjectDisp layForward?objectld=6.

54. John A. Peters, Nicholas M. Barnes, Tim G. Hales, Sarah C. R. Lummis, BeateNiesler. 5-HT3 receptors. Accessed on 04/02/2018. IUPHAR/BPS Guide to PHARMACOLOGY, http:// www.guidetopharmacology.org/GRAC/FamilyDisplayForward? familyld=68. 